\author{
Andrea Paola Diaz \\ CAECE University, Argentina \\ Arda Arikan
}

Akdeniz University, Turkey

\title{
A COMPARISON OF ARGENTINEAN AND TURKISH ENGLISH LANGUAGE TEACHER EDUCATION CURRICULA
}

Summary. In this study, we look at the education of English language teachers in two countries, namely, Argentina and Turkey. We specifically discuss the curricula of the teacher education programs by focusing on the specific courses taken by prospective teachers of English in each country and the steps they have to take to start teaching officially. Methodologically, we studied and analyzed two sample curricula, one from each country, in terms of the titles of the courses offered. While comparing, first, each curriculum was studied individually to understand the general outlook of it in terms of the type of English language teacher it aims to graduate. Hence, we tried to understand to "ideal" teacher that is to be educated for the country's specific needs. Then, courses are grouped under categories and the groups are compared with each other. Results show that the Argentinean curriculum aims at graduating "proficient" language users who will develop their knowledge and practice of the language teaching methods on the job whereas the Turkish curriculum aims to graduate a workforce of teachers who have strong knowledge of teaching methods and who, most probably, will develop their language skills in time. This finding is supported with another which shows that literature and culture-related courses are given a significant place in the curricula offered at Argentinean teacher education institutions whereas little importance is given to literature and culture-related courses in the Turkish curriculum.

Keywords: Argentina; Turkey; English; teacher education; curriculum; prospective teacher.

\section{Introduction}

Argentina and Turkey are two important countries in their regions that are in the process of neoliberal restructuring as "emerging market countries;" both of these countries experienced a major economic crisis during the same year, that is, in 2001 (Öniş, 2006). Despite military interludes and economic hardships, Argentina and Turkey are considered as upper middle income countries (Worldbank Open Data, n.d.). From a cultural perspective, both countries can be considered multicultural in nature. Surprisingly, both populations include descendants of ethnic groups such as Arabs from the Middle East. When the case of education is considered, both countries have experienced continuous "reforms" or changes in their curricula at all levels, including their teacher education systems. 
It is noteworthy that Argentina is often cited as a country in which "radical changes are being made to the curriculum" (Avalos, 2000, p. 465), as is the case with Turkey. Argentina, with its decentralized system of education, differs from Turkey in that it grants autonomy to many educational institutions. Turkey, on the other hand, carried out education according to a centralized system consisting of the Ministry of National Education and The Council of Higher Education. These institutions shape the Turkish education system, while Argentina follows "a system of accreditation of training institutions by a Federal Teacher Education Network" (Avalos, 2000, p. 467). However, both Argentinean and Turkish governments are similar in that they have experienced significant educational reforms, along with having a heterogeneous composition of students, financial hardships, strictly centralized systems, and political challenges and pressures.

In recent decades, the English language has become an asset as the language of technology, commerce, education, entertainment, science, tourism, and the Internet. Argentina, like Turkey, has chosen English as the main foreign language to be included in her national curricula as compulsory courses in primary and secondary schools. Having a federal system of government comprising 23 provinces and the autonomous city of Buenos Aires, Argentinean education has aimed to reach the unification and homogenization of the whole population with a centralized government controlling all activities including the decisions on educational policies affecting the whole nation. However, the Federal Law of Education (Ley Federal de Educación No 24.195) passed in 1993, claimed for the decentralization of education as each province was given jurisdiction over its own educational policies (Porto, 2014). Since then, each institution decides on their curricula; and universities are given total control over their curricula and budget, without the interference of the central government. However, all schools are still under the supervision of the Comisión Nacional de Evaluación $y$ Acreditación Universitaria (CONEAU), which oversees their accreditations. Private universities, not subsided by the government, are supervised by the Consejo de Rectores de Universidades Privadas (CRUP).

It has been only in the last two decades that the English teaching profession has begun to gain importance in Argentina, and just lately, English teachers have been required to be qualified/certified so as to be allowed to 
teach. However, despite this requirement, and because of the surge in popularityof the language in the late 1990s, there was a sudden demand for English teachers in some provinces. Consequently, some advanced English students, were accepted to teach in some institutions in order to make up for the teacher shortage. Unfortunately, there is still a high percentage of non-certified "teachers" working in the private or public sector without having obtained a degree either from a tertiary level institution or a university, the two types of institutions concerned with Foreign Language Teacher Education in Argentina.

The main purpose of tertiary or university level education is to prepare prospective teachers with a native-like proficiency for teaching purposes based on grammar, literature and phonology, allowing them to be fully aware of the language they are going to teach. Prospective teachers are also introduced to other subjects concerned not only with the English language, but with theoretical and practical issues connected to the fields of general education, pedagogiccontent subjects, linguistics, and another foreign language. Most of the subjects are taught in English and it is desirable that the candidates have an UpperIntermediate English level before starting their careers. Since the language level of the introductory courses fall under the B2-level according to the Common European Framework of Reference for Languages (CEFR), the candidates are expected to have a similar language proficiency level. At the University level, the career comprises a four to five-year curriculum. Tertiary level institutions, also known as specialised teacher training colleges, follow the tradition of the French "High Normal School" enhancing vocation and teaching. It takes up to four years to complete tertiary level education, so as to obtain non-degree teaching certificates, diplomas, or associates and bachelor's degrees. Certified tertiary level teachers may teach at primary and secondary schools but not at university level; however to do so they must go in for first degree education called Licenciaturas. After the Law of Higher Education passed in 1995, teachers who have got a certification from a tertiary level with a minimum of 2,800 hours tuition may get their licentiate degree, from the "Ciclos de Licenciatura" (Farías, 2008) or "Ciclos de Complementación Curricular" which take from two to three years, and in general they presuppose some kind of interinstitutional cooperation between tertiary level education and universities. The degree obtained enables the graduate to work throughout the national territory according to the Law of 
Higher Education (art. 41). Research suggests that hiring EFL teachers in Argentina can be handled by committees whose decisions are "made on the basis of professional development in TESOL and awareness of the language needs and difficulties of EFL students" (Kamhi-Stein, 1999, p. 147).

When the case of Turkey is considered, it can be seen that the teacher education system is thoroughly centralized, and the student selection system is competitive. As Karakelle (2006, pp. 17-18) articulates, admission to an undergraduate program requires a high school diploma and a competitive score taken "on the Student Selection Examination - a central university entrance examination administered by the Student Selection and Placement Center (ÖSYM), which is an affiliate of the Council of Higher Education (HEC)." All graduates of English Language Teaching, English or American Literature, English Linguistics and Translation (English) programs (minimum BA-diploma) must take a national exam comprising general education, teaching methods, linguistics, and general culture questions. Then, with the score they attain, they are placed in the appropriate school as English language teachers. Anadolu Öğretmen Lisesi (Anatolian Teacher Preparatory High School) is a four-year high school designed to prepare future teachers to enter universities' teacher education programs. In these high schools, in addition to the core curriculum courses, students take courses in general education theory and methodology, as well as the history of education (Turkey: Secondary Education, n.d.). Students graduating from these schools are given additional points on national university entrance exams to give them an advantage for acceptance to relevant faculties of education.

The 1997 ELT curriculum reform has resulted in upgrading the curriculum of faculties of education in which prospective teachers were educated by means of an increased number of methodology courses and practicum opportunities at primary and secondary schools; this measure is intended to provide student teachers with hands-on experience (Kirkgöz 2005). One of the main changes in the curriculum was the introduction of a new course to be given in two consecutive semesters, titled Teaching English to Young Learners (Kirkgöz, 2007). To meet the shortage of teachers, the Ministry of National Education (MNE), in cooperation with Anadolu University's Open Education Faculty, started a four-year on-line teacher education BA programme (Kirkgöz, 2007) which was 
later closed down without further explanation (see Appendix II for its four-year curriculum). However, this curriculum is more or less similar to those currently offered at all other institutions, because its frame was mandatory for all faculties of education in Turkey.

One of the major problems that both Argentina and Turkey experience in regards to the teaching of English is the lack of qualified and experienced teachers. In Turkey, inexperienced teachers most of whom are new graduates who have taken the national exams, are sent to work in small towns and villages without adequate preparation. For instance, according to the national placement system, when the results of the exam in 2008 are considered, in order to be placed in the Zekai Dede Primary School in İstanbul (Turkey's largest city) as an English language teacher, a prospective teacher attained a score of 81.295; while placement in Rize's Yukarıdurak Primary School (a small-town institution), required only a score of $72.341^{39}$. This shows that if the quality of an English language teacher is measured by the scores obtained from this national test, then primary schools in remote regions or cities hire "less successful teachers," most of whom are new graduates with little teaching experience.

When the case of Argentina is reconsidered, it can be seen that there is high number of non-qualified teachers working in private and public institutions, the majority of whom may lack the experience or knowledge to meet their students' needs. In addition, many qualified teachers move from the public system into the private system in order to get better salaries and a flexible work schedule. This is somewhat different from the case of Turkey where English language teachers, like all other teachers, opt for working for the state, which offers job security and substantial benefits.

In both countries, a further problem is that many teachers, once they obtain their degree and start working, do not have the time or the will to update their professional knowledge mainly because self-development may not have an effect on their future hiring as teachers since only private institutions may require proof of professional development courses attended or activities participated. Consequently, many of those teachers who graduated years ago may still be using traditional teaching techniques, materials and resources. Solving this problem becomes more difficult unless serious action is taken because the

39 See: http://egeake.com/kpss/category/ingilizce/. 
technological appliances teachers must use today remain unknown to a considerable number of teachers who refrain from teaching with technology.

Although English is neither a national nor an official language in Argentina, it is definitely the most important foreign language in the country (Nielsen, 2003), as is the case in Turkey. Similarly, although Nielsen (2003) wrote the following lines specifically to describe the case of Argentina:

Learning English is perceived as a must, but not necessarily enjoyed. English is compulsory at school and it is seen as necessary in seeking further university education. At universities the English language courses are the most popular of the foreign language courses" (p. 208),

this description fits well to the case of Turkey, where English is a compulsory course from the second grade up to the second year of university education.

In this study, we look at the education of English language teachers in the two aforementioned countries. We particularly discuss the curricula of the teacher education programs by focusing on the specific courses taken by prospective teachers of English in each country and the steps they have to take to start teaching officially. While doing that, we tried to understand the "ideal" type of the teacher each country aims to graduate.

\section{Method}

Two sample curricula, one from each country, are compared in terms of the titles of the courses offered. While comparing, first, each curriculum was studied individually to understand its general outlook in terms of the type of English language teacher it aims to graduate. Hence, we tried to understand the "ideal" teacher that is to be educated for the country's specific needs. Then, the courses are grouped under categories, and the groups are compared with each other. Our comparison of curricula of teacher education programs in Argentina (Appendix I) and Turkey (Appendix II) revealed the following similarities and differences given under related headings. 


\section{Findings}

\section{The Desired Type of English Language Teacher}

The general outlook of the two curricula reveals that the Argentinean institution aims to educate and graduate teachers who are proficient in English, with a working knowledge of general culture. For this type of teacher education system, we can easily claim that teaching is to be learned on the job, since courses on teaching methods (pedagogy) are very few. When the Turkish institution is considered, we see the opposite of the Argentinean one. The teacher education curriculum gives greater emphasis to the courses on teaching methods (pedagogy), followed by specific language skills courses.

\section{Language Skills Courses}

The place and weight of courses on developing English language skills in the programs are somewhat similar. While there are 14 skills courses in the Turkish program (Contextual Grammar I through IV, Reading and Writing Skills I and II, Oral Communication Skills I through IV, Listening and Pronunciation I and II, Advanced Reading and Writing Skills I and II) and 2 translation courses, there are 13 courses in the Argentinean one, namely, English I through V, English Phonetics and Phonology I and II, Elements of English Grammar, English Syntax I through III, Elements of English Phonetics and Diction, and English-Spanish Contrastive Analysis. However, considering the number of all courses preservice English language teachers must take in these countries, the weight of language skills courses increases dramatically in the Argentinean one. This result suggests that Argentinean future teachers of English are more likely to be exposed to language skills in English more than their Turkish counterparts do.

\section{Culture-related Courses}

Culture-related courses are given a significant place in the curricula offered at Argentinean teacher education institutions whereas little importance is given to culture-related courses in the Turkish curriculum. The significant place of culture- 
related courses in the Argentinean curricula may be due to the intrinsic importance of culture in Argentina since the nation was made by the immigrants and the indigenous. It was in the early $19^{\text {th }}$ century that Argentina encouraged immigration adopting an open immigration policy as the state offered land, food and accommodation to newly arrived immigrants, subsidized boat passages as well as train tickets, and helped them in finding work. Between 1870 and 1930, known as the "era of mass immigration," Argentina received an uninterrupted flow of immigrants. It is estimated that over 6.6 million immigrants arrived to the country in this period of time (Meter, 2014).

As can be seen in Appendix IV, courses such as Education, Society and Politics, History of Culture and Thought, Contemporary History, Introduction to Philosophy, Psychology I and Psychology II, and Introduction to Sociology are the culture-related courses offered at the Argentinean EL teacher education institution while in its Turkish counterpart Introduction to Education, Introduction to Psychology, History of Culture, Society and Communication, and Fine Arts are the only culture-related courses offered to future EL teachers. This finding is similar to that of Polat and Ogay Barka (2014) who claimed that "preservice teachers from Switzerland had higher intercultural competence than those from Turkey" (p. 31). Polat and Ogay Barka (2014) argue that teacher education curricula in Switzerland include "courses on multiculturalism and intercultural education, while in Turkey no such courses are provided-even as electives" (p. 32). The need for culture-related courses in teacher education curricula seems to be more pressing when Arikan's (2011) study is considered, since it showed that although $92.5 \%$ of preservice English language teachers claim that they have sufficient knowledge of the target language," only "46.6\% claimed to be knowledgeable in the target culture" (p. 235). Hence, future curricular changes in Turkey should include such culture-related courses by considering the cases of other countries and the socio-political changes that have changed the demographics of Turkey where more than 3 million Syrian refugees are now hosted by the state alone.

\section{Pedagogy Courses}

Table 1 shows the foreign language pedagogy courses offered at the Argentinean and Turkish teacher education programs. 


\section{Comparison of Pedagogy Courses}

\begin{tabular}{|l|l|}
\multicolumn{1}{|c|}{ Turkish Institution } & \multicolumn{1}{|c|}{ Argentinean Institution } \\
\hline Teaching Principles and Methods & \\
Teaching English to Young Learners I and II & \\
Approaches in English Language Teaching & \\
Teaching Grammar & \\
Teaching Reading and Listening & General Teaching \\
Teaching Speaking and Writing & Special Teaching and Residency I and II \\
Teaching Reading and Listening I and II & \\
Pedagogical Grammar I and II & \\
School Experience & \\
Teaching Practice & \\
English Language Teaching Methodology & \\
\hline
\end{tabular}

These courses show that preservice English language teachers in Turkey take 11 courses related to language teaching methods or pedagogy while their Argentinean counterparts take only two. This finding is significantly important firstly because the numerical difference between these two sets of courses in these two countries is too wide. Secondly, much research is needed to understand which program is more beneficial and effective when this difference between these two programs is considered.

\section{Literature Courses}

The place and weigh of courses on literature in these programs are significantly different. Although there are five courses (English Literature I through IV) and English Language and Literature in the Argentinean program, there are only two (English-American Literature I and II) in the Turkish one. Considering the view that literary texts exemplify language in use, it seems that the Argentinean preservice teachers are exposed to more target language texts than their Turkish counterparts. Noting that neither of these programs entails courses that include authentic materials from the target language and culture such as films or music, it can be seen that these literature courses remain as an important segment of these curricula when the quality of the language to be taught by these preservice teachers is considered. 


\section{Conclusion}

This study focused on the education of English language teachers in Argentina and Turkey which share some economic and socio-cultural similarities. Comparison of the curricula of the teacher education programs in these countries revealed, most importantly, that the "ideal" English language teacher each country needs is relatively different from one another as the analyses of the courses offered in these programs suggest. It can be inferred that the Argentinean teacher English language teacher education curriculum aims at graduating "proficient" language users who will develop the knowledge and practice of the language teaching methods on the job whereas the Turkish curriculum aims to graduate a workforce of teachers who have strong knowledge of teaching methods and who, most probably, will develop their language skills in time.

Our results related with the weight of language skills courses suggest that Argentinean future teachers of English are more likely to be exposed to knowledge of the language skills during their education more than their Turkish counterparts do. This result, when we consider that the number of literature courses offered in the Argentinean program outperforms those offered in the Turkish one, it can be concluded that Argentinean preservice teachers are more likely to develop themselves as proficient users of English although there is no data available to compare the performance of each group in a way to compare them to understand which teacher education program is likely to develop future teachers as competent users of the language they are to teach.

The major limitation of this study is that it focused only on two exemplary English language teacher education curricula. Although we know that each of the curricula we analyzed is based on the framework employed by majority of the teacher education institutions, we are equally aware that there are differences among various institutions within each country. Hence, future research should employ the analyses of as many curricula as possible while considering the quality of the courses offered as well as the proficiency and the competency of the teachers who are educated as these institutions.

Being at the intersection of Europe and Asia and its proximity to the Middle East and Africa, Turkey plays a vital part in maintaining peace and stability 
Andrea Paola DIAZ, Arda ARIKAN

in the region as a member of the NATO and an applicant to the EU (Kirkgöz, 2007) and both Argentina and Turkey have similar Gross Domestic Products, Turkey ranking 18 while Argentine is ranking 21 in the world. ${ }^{40}$ As developing economies which require establishing stable business and commerce relationships with the rest of the world, both countries realize the importance of English as a medium of communication. Hence, educating English language teachers in both countries requires dynamic changes in the curricula of teacher education programs so as to upgrade both the content of these programs as well as the qualities of the graduates as teachers. Hence, comparing countries' teacher education activities, practices, and laws as specific cases from a historical perspective will inform the program designers about the developments occurring in others which, to our knowledge, may help improving teacher education programs by and large.

\section{References}

Arikan, A. (2011). Prospective English language teachers' perceptions of the target language and culture in relation to their socioeconomic status. English Language Teaching, 4(3), 232-242.

Avalos, B. (2000). Policies for teacher education in developing countries. International Journal of Educational Research, 33, 457-474.

Farías, M (2008). Sociocultural and political issues in English teacher education: policies and training in Argentina, Brazil, Chile and Colombia. In G. Gil \& M. H. Vieria-Abrahao (Eds), Educacao de professores de línguas. Campinas, SP: Pontes.

Kamhi-Stein, L. D. (1999). Preparing non-native Professionals in TESOL: Implications for teacher education programs (pp. 145-162). In G. Braine (Ed.), Non-native educators in English language teaching. New York: Routledge.

Karakelle, S. (2006). The centralized higher education system in Turkey and the national music teacher training program since 1998: An analysis (Unpublished doctoral dissertation). University of North Texas, TX, USA.

40 http://databank.worldbank.org/data/download/GDP.pdf. 
Kirkgöz, Y. (2005). English language teaching in Turkey: Challenges for the $21^{\text {st }}$ century. In G. Braine (Ed.), Teaching English to the world: History, curriculum, and practice. Mahwah: Lawrence Erlbaum Associates.

Kirkgöz, Y. (2007). English language teaching in Turkey: Policy changes and their implementations. RELC Journal, 38(2), 216-228. Doi: $10.1177 / 0033688207079696$.

Meter, A. (2014). Argentina in the era of mass immigration. Latin American Studies. Retrieved from http://oxfordindex.oup.com/view/10.1093/ obo/9780199766581-0163.

Nielses, P. M. (2003). English in Argentina: A sociolinguistic profile. World Englishes, 22(2), 199-209.

Öniş, Z. (2006). Varieties and crises of neoliberal globalisation: Argentina, Turkey and the IMF. Third World Quarterly, 27(2), 239-263.

Polat, S., \& Ogay Barka, T. (2014). Preservice teachers' intercultural competence: A comparative study of teachers in Switzerland and Turkey. Eurasian Journal of Educational Research, 54, 19-38.

Porto, M. (2014). The role and status of English in Spanish-speaking Argentina and its education system nationalism or imperialism? SAGE Open, 4(1). Retrieved from http://sgo.sagepub.com/content/4/1/2158244013514059.

Steiman, J. \& Guerrini, V. (2013). Documentos de la dirección nacional de gestión universitaria (DNGU). Docus $\mathrm{N}^{\circ}$ 1: Las carreras de ciclos de complementación curricular. Ministerio de Educación Dirección Nacional de Gestión Universitaria. Buenos Aires: Ministerio de Cultura y Educación.

World Bank Open Data. (n.d.) In The Worldbank. Retrieved from http://data.worldbank.org/.

Turkey: Secondary Education. (n.d.) In Stateuniversity.com. Retrieved from http://education.stateuniversity.com/pages/1564/Turkey-SECONDARYEDUCATION.html.

Appendix 1.

\section{Universidad Nacional del Comahue - General Roca, Rio Negro, Argentina}

\begin{tabular}{|l|l|l|l|}
\hline \multicolumn{2}{|c|}{$1^{\text {st }}$ Year } & \multicolumn{2}{c|}{$2^{\text {nd }}$ Year } \\
\hline \multirow{4}{*}{ Annual } & English I $(*)$ & \multirow{2}{*}{ Annual } & English II $\left(^{*}\right)$ \\
\cline { 2 - 2 } & Spanish Language Grammar & $\begin{array}{l}\text { English Phonetics and Phonology } \\
\text { I }(*)\end{array}$ \\
\cline { 5 - 5 } & Elements of English Grammar $\left(^{*}\right)$ & $1^{\text {st }}$ Term & English Syntax I $\left(^{*}\right)$ \\
\hline
\end{tabular}


Andrea Paola DIAZ, Arda ARIKAN

\begin{tabular}{|c|c|c|c|}
\hline & $\begin{array}{l}\text { Elements of English Phonetics and } \\
\text { Diction }(*)\end{array}$ & & Psychology I \\
\hline $1^{\text {st }}$ Term & Introduction to Philosophy & & Education, Society and Politics \\
\hline $2^{\text {nd }}$ Term & Introduction to Sociology & \multirow{3}{*}{$2^{\text {nd }}$ Term } & English Syntax II $(*)$ \\
\hline & & & Epistemology \\
\hline & & & $\begin{array}{l}\text { History of Culture and Thought } \\
(*)\end{array}$ \\
\hline & 3rd Year & & 4th Year \\
\hline \multirow{3}{*}{ Annual } & English III $(*)$ & \multirow{3}{*}{ Annual } & English IV $(*)$ \\
\hline & English Phonetics and Phonology II & & $\begin{array}{l}\text { Special Teaching and Residency } \\
\text { I }\end{array}$ \\
\hline & $(*)$ & & $\begin{array}{l}(*) \text { Optional (Portuguese-Italian- } \\
\text { French-German) }\end{array}$ \\
\hline \multirow{3}{*}{$1^{\text {st }}$ Term } & $\begin{array}{l}\text { Semantics and Discourse Analysis } \\
(*)\end{array}$ & \multirow[t]{2}{*}{$1^{\text {st }}$ Term } & $\begin{array}{l}\text { English-Spanish Contrastive } \\
\text { Analysis }(*)\end{array}$ \\
\hline & Psychology II & & English Literature I $\left(^{*}\right)$ \\
\hline & Contemporary History $(*)$ & \multirow{2}{*}{$2^{\text {nd }}$ Term } & Theoretical Linguistics $(*)$ \\
\hline \multirow[b]{2}{*}{$2^{\text {nd }}$ Term } & English Syntax III $(*)$ & & English Literature II $\left(^{*}\right)$ \\
\hline & $\begin{array}{l}\text { Intro. to Eng. Language and } \\
\text { Literature }(*)\end{array}$ & \multirow{8}{*}{\multicolumn{2}{|c|}{$\left(^{*}\right)$ Subjects taught in English. }} \\
\hline \multicolumn{2}{|r|}{$5^{\text {th }}$ Year } & & \\
\hline \multirow[b]{2}{*}{ Annual } & English $\vee(*)$ & & \\
\hline & $\begin{array}{l}\text { Special Teaching and Residency II } \\
(*)\end{array}$ & & \\
\hline \multirow{2}{*}{$1^{\text {st }}$ Term } & Language Acquisition (*) & & \\
\hline & English Literature III $(*)$ & & \\
\hline \multirow{2}{*}{$2^{\text {nd }}$ Term } & Research Seminar $(*)$ & & \\
\hline & English Literature IV $(*)$ & & \\
\hline
\end{tabular}

Appendix 2.

Open University's EL Teacher Education Curriculum, Turkey (BA)

\begin{tabular}{|c|c|c|c|}
\hline $1^{\text {st }}$ Semester & $2^{\text {nd }}$ Semester & $3^{\text {rd }}$ Semester & $4^{\text {th }}$ Semester \\
\hline Computer I & Computer II & $\begin{array}{l}\text { Society and } \\
\text { Communication }\end{array}$ & $\begin{array}{l}\text { Advanced Reading } \\
\text { And Writing Skills III }\end{array}$ \\
\hline $\begin{array}{l}\text { Persuasive } \\
\text { Communication }\end{array}$ & $\begin{array}{l}\text { Contextual Grammar } \\
\text { II }\end{array}$ & $\begin{array}{l}\text { Advanced Reading and } \\
\text { Writing Skills I }\end{array}$ & $\begin{array}{l}\text { Translation (Turkish- } \\
\text { English) }\end{array}$ \\
\hline $\begin{array}{l}\text { Contextual Grammar } \\
\text { I }\end{array}$ & $\begin{array}{l}\text { Reading and Writing } \\
\text { Skills II }\end{array}$ & $\begin{array}{l}\text { Translation (English- } \\
\text { Turkish) }\end{array}$ & $\begin{array}{l}\text { Contextual Grammar } \\
\text { IV }\end{array}$ \\
\hline $\begin{array}{l}\text { Reading and Writing } \\
\text { Skills I }\end{array}$ & $\begin{array}{l}\text { Oral Communication } \\
\text { Skills II }\end{array}$ & $\begin{array}{l}\text { Contextual Grammar } \\
\text { III }\end{array}$ & $\begin{array}{l}\text { Oral Communication } \\
\text { Skills IV }\end{array}$ \\
\hline $\begin{array}{l}\text { Oral Communication } \\
\text { Skills I }\end{array}$ & $\begin{array}{l}\text { Listening and } \\
\text { Pronunciation II }\end{array}$ & $\begin{array}{l}\text { Oral Communication } \\
\text { Skills III }\end{array}$ & Fine Arts \\
\hline $\begin{array}{l}\text { Listening and } \\
\text { Pronunciation I }\end{array}$ & History of Culture & $\begin{array}{l}\text { Teaching Principles } \\
\text { and Methods }\end{array}$ & $\begin{array}{l}\text { Introduction to } \\
\text { Behavioral Science }\end{array}$ \\
\hline $\begin{array}{l}\text { Introduction to } \\
\text { Education }\end{array}$ & Sociology of Education & $\begin{array}{l}\text { Atatürk's Principles } \\
\text { and History of T. R. I }\end{array}$ & $\begin{array}{l}\text { Atatürk's Principles } \\
\text { and History of T. R. } \\
\text { II }\end{array}$ \\
\hline $\begin{array}{l}\text { Introduction to } \\
\text { Psychology }\end{array}$ & & $\begin{array}{l}\text { Turkish Speaking } \\
\text { Skills }\end{array}$ & Turkish Writing Skills \\
\hline
\end{tabular}




\begin{tabular}{|c|c|c|c|}
\hline $5^{\text {th }}$ Semester & $6^{\text {th }}$ Semester & $7^{\text {th }}$ Semester & $8^{\text {th }}$ Semester \\
\hline Linguistics I & Linguistics II & $\begin{array}{l}\text { Instructional } \\
\text { Technologies and } \\
\text { Material Design in } \\
\text { English Language } \\
\text { Teaching I }\end{array}$ & $\begin{array}{l}\text { Instructional } \\
\text { Technologies and } \\
\text { Material Design in } \\
\text { English Language } \\
\text { Teaching II }\end{array}$ \\
\hline $\begin{array}{l}\text { Teaching English to } \\
\text { Young Learners I }\end{array}$ & $\begin{array}{l}\text { Teaching English to } \\
\text { Young Learners II }\end{array}$ & $\begin{array}{l}\text { Pedagogical Grammar } \\
\text { I }\end{array}$ & $\begin{array}{l}\text { Pedagogical } \\
\text { Grammar II }\end{array}$ \\
\hline Approaches in ELT & Teaching Grammar & Language Acquisition & Teaching Practice \\
\hline $\begin{array}{l}\text { Teaching Reading } \\
\text { and Listening }\end{array}$ & $\begin{array}{l}\text { Teaching Speaking } \\
\text { And Writing }\end{array}$ & $\begin{array}{l}\text { EL Testing and } \\
\text { Evaluation I }\end{array}$ & $\begin{array}{l}\text { EL Testing and } \\
\text { Evaluation II }\end{array}$ \\
\hline $\begin{array}{l}\text { English-American } \\
\text { Literature I }\end{array}$ & $\begin{array}{l}\text { English-American } \\
\text { Literature II }\end{array}$ & Guidance & $\begin{array}{l}\text { Turkish Education } \\
\text { System and School } \\
\text { Management }\end{array}$ \\
\hline $\begin{array}{l}\text { Classroom } \\
\text { Management }\end{array}$ & $\begin{array}{l}\text { Educational } \\
\text { Psychology }\end{array}$ & ELT Methodology & $\begin{array}{l}\text { Turkish Syntax and } \\
\text { Semantics }\end{array}$ \\
\hline \multirow[t]{2}{*}{$\begin{array}{l}\text { Community Services } \\
\text { in ELT I }\end{array}$} & $\begin{array}{l}\text { Community Services } \\
\text { in ELT II }\end{array}$ & School Experience & \\
\hline & & $\begin{array}{l}\text { Turkish Phonology and } \\
\text { Morphology }\end{array}$ & \\
\hline
\end{tabular}

\section{Andrea Paola Diaz}

CAECE universitetas, Argentina; and.d_cs@hotmail.com

\section{Prof. Dr Arda Arikan}

Akdeniz universitetas, Turkija; ardaari@gmail.com

\section{ARGENTINOS IR TURKIJOS ANGLU KALBOS MOKYTOJU RENGIMO TURINIO PALYGINIMAS}

Santrauka. Šiame tyrime analizuojame anglu kalbos mokytoju rengima dviejose šalyse, Argentinoje ir Turkijoje. Nagrinejjame mokytoju rengimo programu turini (curriculum), akcentuodami specifiniu dalyku, kuriuos būsimi anglu kalbos mokytojai studijuoja kiekvienoje šalyje, svarba ir žingsnius, kuriuos mokytojai turi praeiti prieš pradèdami oficialiai dirbti mokytojais. Metodologine prasme studijavome ir analizavome dvieju pavyzdiniu anglu kalbos mokytoju rengimo turiniu sandara, t. y. kokie dalykai siūlomi kiekvienos šalies mokytoju rengimo programose. Prieš atliekant abieju šaliu mokytoju rengimo turinio analizę, kiekvieną mokymo turini išanalizavome individualiai, bandydami suprasti bendra situacija ir tiksla, koki anglu kalbos mokytoja mokymo programa siekia išugdyti. Stengèmès suprasti "idealaus" mokytojo modeli, kuris atitinka šalies specifinius poreikius. Tada visus mokytoju rengimo turinio dalykus sugrupavome i atskiras kategorijas ir palyginome šias grupes abiejose šalyse. Tyrimo rezultatai rodo, kad Argentinos kalbu mokytoju rengimo programos siekia išugdyti igudusius kalbos vartotojus, kurie tobulins savo žinias ir kalbos mokymo metodus praktiškai dirbdami mokytojais. Turkijos mokytoju rengimo programos turinys, atvirkščiai, siekia parengti kalbu mokytojus, kurie būtu profesionaliai pasirengę mokymo metodu srityje, bet kurie, tikètina, tobulins savo kalbinius gebejjimus dirbdami. Siuos tyrimo rezultatus papildo duomenys apie dalykus, susijusius su literatūra ir kultūra. Rezultatai rodo, kad Argentinos mokytoju rengimo institucijose skiriamas didelis demesys literatūros ir kultūros dalykams, o Turkijos mokytoju rengimo programos neskiria didelès reikšmès su literatūra ir kultūra susijusiems dalykams.

Pagrindinès sąvokos: Argentina, Turkija, anglu kalba, mokytoju rengimas, mokymo turinys, būsimasis mokytojas. 